\title{
NOTES ON THE COATI, Nasua nasua (CARNIVORA: PROCYONIDAE) IN AN ATLANTIC FOREST AREA
}

\author{
BEISIEGEL, B. M. \\ Departamento de Ecologia Geral, Instituto de Biociências da Universidade de São Paulo, Brazil \\ Correspondence to: Beatriz de Mello Beisiegel, Al. São Luiz, 635, Granja Viana, CEP 06700-000, Cotia, SP, Brazil, \\ e-mail: beatrizb@usp.br \\ Received November 7, 2000 - Accepted November 27, 2000 - Distributed November 30, 2001
}

\begin{abstract}
Although Nasua nasua is broadly distributed geographically and relatively common, it is still little studied. This paper reports observations of coatis in an Atlantic Forest area, the Parque Estadual Carlos Botelho (PECB) in São Paulo State, Brazil. The social structure of coatis at PECB seems to be the same related in the literature. The mating season appears to be August-September and the pups are born in October-November. Coatis are mainly arboreal at the PECB, contrasting with habits reported in the data from other areas. This preference for the arboreal stratum no doubt is related to their foraging in epiphytic bromeliads, which occurred in $90.6 \%$ of the instances in which they were observed feeding. Bromeliads are a rich food source much more common in the Atlantic Forest than in other areas where coatis have been observed. This result suggests that this species is able to adjust its foraging and strata preferences to different environments without changing its basic social structure.
\end{abstract}

Key words: Nasua nasua, Atlantic Forest, behavior, life history.

\section{RESUMO}

\section{Notas sobre o quati Nasua nasua (Carnivora: Procyonidae) em uma área de Mata Atlântica}

Embora Nasua nasua seja uma espécie amplamente distribuída e relativamente comum, ainda é pouco estudada. Este artigo relata observações dos quatis em uma área de Mata Atlântica, o Parque Estadual Carlos Botelho, SP (PECB). A estrutura social dos quatis parece estar de acordo com a sugerida pela literatura e a provável época de acasalamento no PECB é agosto-setembro; os filhotes devem nascer em outubro-novembro. Os quatis são, principalmente, arborícolas no PECB, ao contrário do que foi observado em outras áreas. Esta preferência pelo estrato arbóreo deve estar relacionada ao forrageamento em bromélias epífitas, que ocorreu em $90,6 \%$ dos encontros em que os quatis foram observados comendo. As bromélias são uma fonte alimentar rica e são muito mais abundantes na Mata Atlântica do que em outros locais onde os quatis foram observados. Este resultado sugere que essa espécie é capaz de ajustar suas preferências de uso de estrato e modo de forrageamento às diferentes condições ambientais sem alterar sua estrutura social básica.

Palavras-chave: Nasua nasua, Mata Atlântica, comportamento, história de vida.

\section{INTRODUCTION}

Nasua nasua is a procionid with broadly distributed in South America, ranging from Colombia and Venezuela to Northern Uruguay and Argentina. It occupies essentially forested habitats, including deciduous and evergreen forests; gallery and cloud forests; chaco; and savanna. It is diurnal, scansorial and omnivore, feeding mainly on invertebrates and fruits (Redford \& Stearman, 1993; Gompper \& Decker, 1998). The social organization of the species is similar to that of the white- 
nosed coati, Nasua narica (Russel, 1983, 1996): females and juveniles live in groups of up to 30 individuals and males older than two years are solitary (Gompper \& Decker, 1998).

Despite its broad geographical distribution, relative abundance and great ethological interest, most data on the behavior and ecology of Nasua nasua are from incidental studies and general mammal guides (for a review see Gompper \& Decker, 1998) and no studies exist on those in the Atlantic Forest. In this article, I report behavioral, ecological, and life history aspects of coatis in an Atlantic Forest area. The observations were conducted as a pilot study for a long-term project on the ecology and behavior of coatis.

\section{MATERIAL AND METHODS}

\section{Study area}

Observations were made at Parque Estadual Carlos Botelho (PECB), a 37,644 ha area in São Paulo State $\left(24^{\circ} 00^{\prime}-24^{\circ} 15^{\prime}\right.$ ' South and $47^{\circ} 45^{\prime}$ $48^{\circ} 10^{\prime}$ West). The altitudes in the study area range from 700 to 839 meters. The climate is type Cfa and $\mathrm{Cfb}$ of Koppen, described as mesothermic humid without a dry winter. Annual precipitation is 1,475 to $2,582 \mathrm{~mm}$ and average precipitation in the driest month is $49 \mathrm{~mm}$ (Pfeifer et al., 1986). Average temperatures are $18^{\circ} \mathrm{C}$ to $20^{\circ} \mathrm{C}$, with a minimum of $3^{\circ} \mathrm{C}$ and maximum of $29^{\circ} \mathrm{C}$ (Domingues et al., 1987; Domingues \& Silva, 1988).

Vegetation is Latifoliate Pluvial Tropical Forest (Domingues \& Silva, 1988). The study area comprised mainly primary forest, although logging has occurred in many places in the past, and there were some patches of secondary forest and more recent "capoeira".

\section{Observations}

The data reported here were collected between February 1997 and October 1999. Initially, the animals were observed only by chance, but from May 1999 on, a systematic effort to locate the animals began. The search method consisted in walking slowly through places where the animals had been seen. The observations were made by the ad libitum method. Group composition, site of encounter, stratum where they were seen (arboreal or terrestrial), reaction of the animals to the presence of the observer, and what or where the animals were eating were registered whenever possible.

\section{RESULTS}

Coatis were observed for a total of 68 hours distributed in 60 encounters. Once a group was located, it was relatively easy to accompany the animals for periods of up to six hours; however, we never found a group for two consecutive days. Coatis don't have loud vocalizations such as those emitted by such groups of primates as Cebus apella, Brachyteles arachnoides and Alouatta fusca, which often allow their localization by researchers in the Atlantic Forest. Also, their locomotion and foraging are much more silent than those of $C$. apella and B. arachnoides; coatis are thus more difficult to localize than these primates, as they may not be perceived even by an observer walking nearbye a group.

Coatis were found mainly in groups $(76.3 \%$ of the encounters vs. $23.7 \%$ of the encounters with solitary animals; $\mathrm{N}=58, \chi^{2}=11.655, \mathrm{df}=1, \mathrm{p}=$ $0.001)$; most groups $(35.6 \%)$ were of 5 to 10 individuals and the average group size was 7.4. It was possible to divide the animals on sight into three size classes that were termed adult (full-sized coatis), subadult (smaller than adults), and juvenile (with characteristics such as darker fur, greater head/body proportion and slower locomotion). However, as these must just roughly correspond to actual age classes, they were not used for quantitative analysis, but rather for a rough estimate of group composition. Solitary individuals were adults $(n=12)$ or subadults $(n=2)$. Groups could be composed of adults, subadults and juveniles; or of adults and juveniles; or of adults and subadults; or just adults. The smallest juveniles were seen in December and January when they were roughly $20 \mathrm{~cm}$ long, tail included.

Coatis were found mainly on trees $(69.5 \%$ vs. $30.5 \%$ of encounters with coatis on the ground; $\mathrm{N}=59$, binomial test, $\mathrm{p}=0.004)$. They displayed different reactions after they perceived a human observer: escape by the same stratum they were using when seen; escape by changing the stratum (climbing trees when they were seen on the ground or descending to the ground when they were seen in trees); emission of an alarm vocalization termed "cough" and no escape; or no observable reaction. 
In the 32 encounters for which reaction of the animals to the observer was noted, there was no significant difference between the frequency of occasions in which the animals escaped $(n=14)$ or did not escape $(\mathrm{n}=18$, binomial test, $\mathrm{p}=$ 0.596). They failed to escape more when they were in trees $(n=16)$ than when they were on the ground $(\mathrm{n}=2$, binomial test, $\mathrm{p}=0.001)$. When they did not escape, they vocalized alarm in nine encounters and presented no reaction in nine encounters. Generally, coatis seemed more at ease in trees (where they were seen 41 times, of these fleeing 6 times [14.6\%] 4 of which descending to the ground) than on the ground (where they were seen 18 times, escaping 8 times [44.4\%] 7 of these climbing up trees).

Coatis were observed foraging in 32 encounters. In $90.6 \%$ of these encounters they were extracting items from between leaves of epiphytic bromeliads (Bromeliaceae) with their front paws and/or snout. Although it was not possible to see what they were eating (as already noted by Russel, 1996) it probably consisted of invertebrates and small vertebrates, such as anuran amphibians. In $34.4 \%$ of the encounters in which coatis were foraging, they ate fruits; in $15.6 \%$ they foraged by digging little holes on the ground or by revolving the litter with their front paws, probably to capture invertebrates; and in $9.4 \%$ they were observed eating flowers. The difference between these foraging modes was significant $\left(\mathrm{N}=48, \chi^{2}=35.0\right.$, $\mathrm{df}=3, \mathrm{p}<0.001$ ) even if only the two most frequent categories, foraging in bromeliads and eating fruits, are compared (binomial test, $\mathrm{p}<0.007$ ). Coatis were also observed capturing insects on palm leaves.

\section{DISCUSSION}

These data have some aspects in common with the present knowledge of coatis but extend this knowledge in other ways. The number of individuals in coati groups observed in the PECB is in accordance with those observed by Emmons (1990) and Gompper \& Decker (1998). The composition of groups also seems coherent with the social organization proposed by these authors: solitary animals are males older than two years. Groups always contained one or more adults that might be reproductive females, and differences in the composition of subadults and juveniles could be attributed to variation in survival rates.

Very small juveniles moving clumsily were observed only in December and January, suggesting a definite mating season with reproductive synchrony among females. In December 2, 1998, I ran into a group composed of only one adult and three young which took several minutes to flee a distance of five meters from me. In Nasua narica, females leave the groups to give birth in tree nests and rejoin the groups with their pups when they are a few weeks old. By this time, they can spend some time alone with their pups, until they find the group again. The pups are of very small size and have not achieved full locomotor competence when they leave the nest (Russel, 1983, 1996). It is very probable that the group observed by me in December 1998 was composed of a female and her three pups in the very short period between leaving the nest and finding the group. Since females of Nasua nasua rejoin the groups when pups are around 5-6 weeks of age (Emmons, 1990), it appears that the birth period in the PECB is October-November and as, the gestation period is 7477 days (Gompper \& Decker, 1998), the mating season must be in August-September.

Coatis seem to be mainly arboreal in the PECB, in contrast with the observation of Gompper \& Decker (1998) and McClearn et al. (1996) that these animals are predominantly terrestrial, climbing up and down easily by small trees and vines but finding it difficult to move on the trunks of larger trees. In PECB, coatis were observed climbing up and descending large trunks (> $50 \mathrm{~cm} \mathrm{Dbh}$ ). This species inhabit a great variety of environments and probably the stratum preferred by them depends on relative resource availability and predator risk in each, which vary from area to area. The higher use of arboreal stratum in the PECB is probably due to the role of bromeliads in the foraging of coatis. Bromeliads are a rich food source due to the fauna contained in the "tanks" of water imprisoned between their leaves (Hadel, 1989). Southeastern Brazil is the major center of bromeliad diversity (Hadel, 1989; Dov Por, 1992), and the density of bromeliads in the Atlantic Forest is much higher than in the Central American rainforest, where Nasua narica has been studied. The observed preference for trees is reinforced by the higher frequency of absence of escape when in trees, 
although this is a comprehensible reaction to a terrestrial menace (the human observer). Another form of foraging was suggested by camera traps and sand layers placed in the entrances of dens on the ground to identify their inhabitants (Beisiegel, 1999). Coatis frequently entered these dens, probably foraging for invertebrates and little vertebrates inside them. They also used to pluck off the electric tape that was used on the sensors of the camera traps, probably as a reflex of the foraging mode of extracting leaves and pieces of dead logs to find hidden invertebrates and larvae (Emmons, 1990).

Because it is so difficult to see what coatis are eating, diet must be determined by fecal analysis in future studies. Only this analysis will show if the differences in stratum preferences and modes of foraging are reflected in diet composition.

The high frequency of absence of escape in spite of the human observer and the possibility of following a group for long periods suggest the viability of habituating the animals to observational study; however, the difficulty of finding a group for two consecutive days points to the necessity of radio-tracking.

Coatis seem to be able to adapt to a broad range of habitats by changing preferred foraging modes and strata, without changing their basic social structure. However, it remains to be understood if small social characteristics change to adjust to different environments.

Acknowledgments - Pedro Paulino Soares helped immeasurably in data collection. I thank Prof. César Ades for his advisory on my doctoral project, during which these observations were made, and an anonymous referee for improvement of the manuscript. This work had the support of CNPq, Fapesp (grant \# 96/1217-6), Fundação O Boticário de Proteção à Natureza (grant \# 0290971), and WWF (grant \# CRS-080-97).

\section{REFERENCES}

BEISIEGEL, B. M., 1999, Contribuição ao estudo da história natural do cachorro-do-mato, Cerdocyon thous, $e$ do cachorro vinagre, Speothos venaticus. Doctoral dissertation, Universidade de São Paulo.
DOMINGUES, E. N. \& SILVA, D. A., 1988, Geomorfologia do Parque Estadual Carlos Botelho. Boletim Técnico do Instituto Florestal, 42: 71-105.

DOMINGUES, E. N., SILVA, D. A. \& VELLARDI, A. C. V., 1987, Correlações topogeomorfológicas, geológicas e de declividades do Parque Estadual Carlos Botelho, SP. Boletim Técnico do Instituto Florestal, 41: 377-420.

DOV POR, F., 1992, Sooretama: The Atlantic Rainforest of Brazil. SBP Academic Publications, The Hague, 130p.

EMMONS, L. H., 1990, Neotropical rainforest mammals. University of Chicago Press, Chicago, 281p.

GOMPPER, M. E. \& DECKER, D. M., 1998, Nasua nasua. Mammalian Species, 580: 1-9.

HADEL, V. F., 1989, A fauna associada aos fitotelmata bromelícolas da Estação Ecológica da Juréia, Itatins, SP. Doctoral Dissertation, Universidade de São Paulo.

MCCLEARN, D., ROMAN, H., HORAN, S. \& ROSE, W., 1996, Canopy mammal trapping on Barro Colorado Island, Panama: a six month survey. Selbyana, 17: 27-35.

PFEIFER, R. M., CARVALHO, W. A., SILVA, D. A., ROSSI, M. \& MENDICINO, L. F., 1986, Levantamento semidetalhado dos solos do Parque Estadual Carlos Botelho. Boletim Técnico do Instituto Florestal, 40: 75-109.

REDFORD, K. H. \& STEARMAN, A. M. L., 1993, Notas sobre la biologia de tres procionidos simpatricos bolivianos (Mammalia, Procyonidae). Ecol. en Boliv., 21: 3544.

RUSSEL, J. K., 1983, Altruism in coati bands: nepotism or reciprocity? In: S. K. Wasser (ed.), Social behavior of female vertebrates. Academic Press, New York, pp. 263 290.

RUSSEL, J. K., 1996, Timing of reproduction by coatis ( $\mathrm{Na}$ sua narica) in relation to fluctuations in food resources. In: E. G. Leigh Jr., A. S. Rand \& D. M. Windsor (eds.), The ecology of a tropical forest. 2. ed. Smithsonian Institution Press, Washington, DC, pp. 413-431. 